\title{
Terrabacter terrigena sp. nov., isolated from soil
}

Correspondence
Jung-Hoon Yoon
jhyoon@kribb.re.kr

\author{
Jung-Hoon Yoon, ${ }^{1}$ Sooyeon Park, ${ }^{1}$ So-Jung Kang, ${ }^{1}$ Yong-Taek Jung ${ }^{1}$ \\ and Wonyong $\mathrm{Kim}^{2}$ \\ ${ }^{1}$ Korea Research Institute of Bioscience and Biotechnology (KRIBB), PO Box 115, Yusong, \\ Taejon, Republic of Korea \\ ${ }^{2}$ Department of Microbiology, College of Medicine, Chung-Ang University, 221 Heukseok-dong, \\ Seoul, Republic of Korea
}

\begin{abstract}
A Gram-positive-staining, non-motile and rod-shaped bacterium, strain $\mathrm{ON}_{10}^{\top}$, was isolated from soil around a wastewater treatment plant in Korea and its taxonomic position was investigated by using a polyphasic approach. Strain $\mathrm{ON} 10^{\top}$ grew optimally at $\mathrm{pH} 6.5-7.0$ and $30{ }^{\circ} \mathrm{C}$ in the presence of $0.5 \%(\mathrm{w} / \mathrm{v}) \mathrm{NaCl}$. Phylogenetic analysis based on 16S rRNA gene sequences showed that strain $\mathrm{ON} 10^{\top}$ clustered with the clade comprising Terrabacter species, with which it exhibited 16S rRNA gene sequence similarity values of 98.4-98.8\%. The cell-wall peptidoglycan type was based on LL-diaminopimelic acid and the cell-wall sugars were glucose, mannose, arabinose and xylose. The predominant menaquinone was $\mathrm{MK}-8\left(\mathrm{H}_{4}\right)$. The major polar lipids were diphosphatidylglycerol, phosphatidylglycerol, phosphatidylethanolamine, phosphatidylinositol, an unidentified phospholipid and an unidentified lipid. The major fatty acids were iso- $\mathrm{C}_{15: 0}$ and iso$\mathrm{C}_{14: 0}$. The DNA G $+\mathrm{C}$ content was $71.6 \mathrm{~mol} \%$. Strain $\mathrm{ON}_{10}{ }^{\top}$ exhibited DNA-DNA relatedness levels of 17-28\% to the type strains of Terrabacter species and could also be differentiated from these species by differences in phenotypic characteristics. On the basis of the data obtained, strain $\mathrm{ON}_{10} 0^{\top}$ was considered to represent a novel species of the genus Terrabacter, for which the name Terrabacter terrigena sp. nov. is proposed. The type strain is $\mathrm{ON}^{\top} 0^{\top}$ (=KCTC $19602^{\top}=$ CCUG $57508^{\top}$ ).
\end{abstract}

The genus Terrabacter was created by Collins et al. (1989) through the reclassification of Pimelobacter tumescens as Terrabacter tumescens. Subsequently, three further species, Terrabacter terrae (Montero-Barrientos et al., 2005), Terrabacter aerolatus (Weon et al., 2007) and Terrabacter lapilli (Lee et al., 2008), were described. Phylogenetic analyses based on $16 \mathrm{~S}$ rRNA gene sequences showed that the genus Terrabacter falls within the family Intrasporangiaceae in the order Actinomycetales (Stackebrandt et al., 1997; Lee et al., 2008). In this study, we describe a Terrabacter-like bacterial strain that was isolated from soil around a wastewater treatment plant in Korea.

Strain $\mathrm{ON}^{\mathrm{T}}$ was isolated by using dilution plating onto nutrient agar (Difco) at $30{ }^{\circ} \mathrm{C}$. The type strains of the four Terrabacter species were used as reference strains for DNADNA hybridization and phenotypic characterization. $T$. tumescens KCTC $9133^{\mathrm{T}}$ and T. lapilli KCTC $19199^{\mathrm{T}}$ were obtained from the Korean Collection for Type Cultures. T. terrae KACC $11642^{\mathrm{T}}$ and T. aerolatus KACC $20556^{\mathrm{T}}$ were obtained from the Korean Agricultural Culture Collection. The morphological, physiological and biochemical characteristics of strain $\mathrm{ON} 10^{\mathrm{T}}$ were investigated using routine

The GenBank/EMBL/DDBJ accession number for the 16S rRNA gene sequence of strain ON10 ${ }^{\top}$ is FJ423552. cultivation on trypticase soy agar (TSA; Difco) at $30{ }^{\circ} \mathrm{C}$. Cell morphology was examined by light microscopy (Eclipse E600; Nikon) using cells from exponentially growing cultures. The Gram reaction was determined using the bioMérieux Gram Stain kit according to the manufacturer's instructions. Growth at various temperatures $\left(4,10,20,25,28,30,35,37,40\right.$ and $\left.45{ }^{\circ} \mathrm{C}\right)$ was measured on TSA. The $\mathrm{pH}$ range for growth was determined in nutrient broth (Difco) with the $\mathrm{pH}$ adjusted prior to sterilization to various values $(\mathrm{pH} 4.5-10.5$ at intervals of 0.5 units) by the addition of $\mathrm{HCl}$ or $\mathrm{Na}_{2} \mathrm{CO}_{3}$. Growth at various $\mathrm{NaCl}$ concentrations $(0,0.5,1.0,2.0,3.0$, 4.0 and $5.0 \%, \mathrm{w} / \mathrm{v}$ ) was investigated using trypticase soy broth (TSB; Difco) prepared according to the manufacturer's instructions except that $\mathrm{NaCl}$ was added to the desired final concentration. Growth under anaerobic conditions was determined by incubation in an anaerobic chamber on TSA and on TSA supplemented with potassium nitrate $(0.1 \%$, w/v), which had been prepared anaerobically under a nitrogen atmosphere. Catalase and oxidase activities and hydrolysis of casein, gelatin, hypoxanthine, starch, Tweens 20, 40, 60 and 80, tyrosine, urea and xanthine were determined as described by Cowan \& Steel (1965). Hydrolysis of aesculin and nitrate reduction were studied as described by Lányí (1987). Susceptibility to 
antibiotics was tested on TSA plates using antibiotic discs containing the following ( $\mu \mathrm{g}$ unless otherwise stated): polymyxin B (100 U), streptomycin (50), penicillin G (20 U), chloramphenicol (100), ampicillin (10), cephalothin (30), gentamicin (30), novobiocin (5), tetracycline (30), kanamycin (30), lincomycin (15), oleandomycin (15), neomycin (30) and carbenicillin (100). Utilization of a range of various substrates, enzyme activities and other physiological and biochemical properties were tested by using the API 20E, API 20NE, API $50 \mathrm{CH}$ and API ZYM systems (bioMérieux). The cells were suspended in AUX medium, according to the manufacturer's instructions, to inoculate the API $50 \mathrm{CH}$ system.

Cell biomass of strain $\mathrm{ON} 10^{\mathrm{T}}$ for DNA extraction and for the analyses of cell-wall composition, polar lipids and isoprenoid quinones was obtained after incubation in TSB at $30{ }^{\circ} \mathrm{C}$. Chromosomal DNA was isolated and purified according to the method described by Yoon et al. (1996), with the exception that RNase $\mathrm{T} 1$ was used in combination with RNase A to minimize contamination with RNA. The $16 \mathrm{~S}$ rRNA gene sequence was amplified using PCR with two universal primers, 5'-GAGTTTGATCCTGGCTCAG$3^{\prime}$ and $5^{\prime}$-AGAAAGGAGGTGATCCAGCC- ${ }^{\prime}$, as described by Yoon et al. (1998) and sequencing of the amplified sequence was performed as described by Yoon et al. (2003). Alignment of sequences was carried out with CLUSTAL W software (Thompson et al., 1994). Gaps at the 5' and 3' ends of the alignment were excluded from further analysis. Phylogenetic trees were inferred with three tree-making algorithms, the neighbour-joining (Saitou \& Nei, 1987), maximum-likelihood (Felsenstein, 1981) and maximumparsimony (Kluge \& Farris, 1969) methods implemented within the PHYLIP package (Felsenstein, 1993). Evolutionary distance matrices for the neighbour-joining method were calculated with the algorithm of Jukes \& Cantor (1969) using the program DNADIST. The stability of relationships was assessed with a bootstrap analysis based on 1000 resamplings of the neighbour-joining dataset by using the programs SEQBOOT, DNADIST, NEIGHBOR and CONSENSE of the PHYLIP package.

The isomer type of the diamino acid in the cell-wall peptidoglycan was analysed using TLC according to the method described by Komagata \& Suzuki (1987). Wholecell sugars were determined as described by Komagata \& Suzuki (1987). Isoprenoid quinones were extracted according to the method of Komagata \& Suzuki (1987) and analysed using reversed-phase HPLC and a YMC ODS-A $(250 \times 4.6 \mathrm{~mm})$ column. For cellular fatty acid analysis, cell mass was harvested from TSA plates after incubation for 7 days at $30{ }^{\circ} \mathrm{C}$. The fatty acids were extracted and fatty acid methyl esters were prepared according to the standard protocol of the MIDI/Hewlett Packard Microbial Identification System (Sasser, 1990). Polar lipids were extracted according to the procedures described by Minnikin et al. (1984) and identified by two-dimensional TLC followed by spraying with appropriate detection reagents (Minnikin et al., 1984; Komagata \& Suzuki, 1987).
The DNA G + C content was determined by the method of Tamaoka \& Komagata (1984) except that the DNA was first hydrolysed and the resultant nucleotides were analysed by reversed-phase HPLC. DNA-DNA hybridization was performed fluorometrically according to the method of Ezaki et al. (1989) using photobiotin-labelled DNA probes and microdilution wells. Hybridization was performed with five replications for each sample. The highest and lowest values obtained with each sample were excluded, and the mean of the remaining three values was calculated for the DNA-DNA relatedness value.

The almost-complete 16S rRNA gene sequence of strain $\mathrm{ON} 10^{\mathrm{T}}$ comprised 1477 nucleotides. Comparative sequence analysis showed that strain $\mathrm{ON} 10^{\mathrm{T}}$ is phylogenetically most closely related to the family Intrasporangiaceae. In the neighbour-joining phylogenetic tree (Fig. 1), strain $\mathrm{ON} 10^{\mathrm{T}}$ clustered with the clade comprising Terrabacter species, with a bootstrap value of $96.0 \%$. Strain $\mathrm{ON} 10^{\mathrm{T}}$ exhibited $16 \mathrm{~S}$ rRNA gene sequence similarity values of $98.4-98.8 \%$ with the type strains of Terrabacter species and less than $97.7 \%$ with the other species used in the phylogenetic analysis. Strain $\mathrm{ON} 10^{\mathrm{T}}$ exhibited DNA-DNA relatedness of $17-28 \%$ to the type strains of Terrabacter species: T. tumescens KCTC $9133^{\mathrm{T}}(28 \%)$, T. terrae KACC $11642^{\mathrm{T}}(19 \%)$, T. aerolatus KACC $20556^{\mathrm{T}}(17 \%)$ and T. lapilli KCTC $19199^{\mathrm{T}}(20 \%)$. These values indicated that strain $\mathrm{ON} 10^{\mathrm{T}}$ represents a genomic species different from the currently recognized Terrabacter species (Wayne et al., 1987).

Strain $\mathrm{ON} 10^{\mathrm{T}}$ had LL-2,6-diaminopimelic acid as the diagnostic diamino acid in the cell-wall peptidoglycan. The cell-wall sugars were glucose, mannose, arabinose and xylose. The predominant isoprenoid quinone detected in strain $\mathrm{ON} 10^{\mathrm{T}}$ was menaquinone- $8\left(\mathrm{H}_{4}\right)$. Major polar lipids

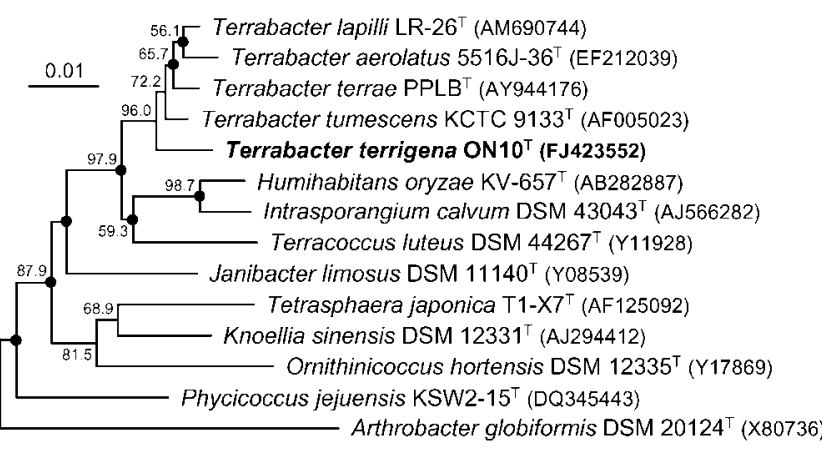

Fig. 1. Neighbour-joining phylogenetic tree based on 16S rRNA gene sequences showing the positions of Terrabacter terrigena sp. nov. $\mathrm{ON} 10^{\top}$ and some other related taxa. Bootstrap values (>50\%) based on 1000 replications are shown at branch nodes. Filled circles indicate that the corresponding nodes were also recovered in the trees generated with the maximum-likelihood and maximum-parsimony algorithms. Arthrobacter globiformis DSM $20124^{\top}$ was used as the outgroup. Bar, 0.01 substitutions per nucleotide position. 
found in strain $\mathrm{ON}_{10} 0^{\mathrm{T}}$ were diphosphatidylglycerol, phosphatidylglycerol, phosphatidylethanolamine, phosphatidylinositol, an unidentified phospholipid and an unidentified lipid. The fatty acid profile of strain $\mathrm{ON} 10^{\mathrm{T}}$ was composed of the following (each constituting $>0.5 \%$ of total fatty acids): branched fatty acids iso- $\mathrm{C}_{15: 0}(48.2 \%)$, iso- $\mathrm{C}_{14: 0}(13.5 \%)$, anteiso- $\mathrm{C}_{15: 0}(8.2 \%)$, iso- $\mathrm{C}_{16: 1}$ $(6.2 \%)$, iso- $\mathrm{C}_{16: 0}(5.9 \%)$, iso- $\mathrm{C}_{17: 1} \omega 9 c(1.1 \%)$, anteiso-
$\mathrm{C}_{17: 1} \omega 9 c(0.9 \%)$, iso- $\mathrm{C}_{13: 0}(0.8 \%)$ and anteiso- $\mathrm{C}_{17: 0}$ $(0.6 \%)$; summed feature 1 (iso- $\mathrm{C}_{15: 1}$ and/or $\mathrm{C}_{13: 0} 3-\mathrm{OH}$; $2.9 \%)$; unsaturated fatty acids $\mathrm{C}_{15: 1} \omega 6 c(2.8 \%)$ and $\mathrm{C}_{17: 1} \omega 8 c(2.6 \%)$; summed feature $3\left(\mathrm{C}_{16: 1} \omega 7 c\right.$ and/or iso- $\left.\mathrm{C}_{15: 0} 2-\mathrm{OH} ; 1.9 \%\right)$; and straight-chain fatty acids $\mathrm{C}_{15: 0}$ $(1.8 \%)$ and $\mathrm{C}_{16: 0}(0.6 \%)$. This fatty acid profile was similar to those of other Terrabacter species, although there may be differences in the proportions of some fatty acids

\section{Table 1. Differential phenotypic characteristics of strain $\mathrm{ON} 10^{\top}$ and the type strains of Terrabacter species}

Taxa: 1, strain ON10 ${ }^{\mathrm{T}}$ (Terrabacter terrigena sp. nov.); 2, T. tumescens (data from Collins et al., 1989; Montero-Barrientos et al., 2005; Weon et al., 2007); 3, T. terrae (Montero-Barrientos et al., 2005; Weon et al., 2007); 4, T. aerolatus (Weon et al., 2007); 5, T. lapilli (Lee et al., 2008; this study). All taxa are Gram-positive-staining and positive for catalase, hydrolysis of aesculin and gelatin (not determined for T. lapilli), utilization of Dglucose, maltose, sucrose, inositol, $N$-acetylglucosamine, gluconate, glycogen and malate, and activities of esterase lipase (C8), leucine arylamidase, acid phosphatase, $\alpha$ - and $\beta$-galactosidase and $\alpha$-glucosidase. All taxa are negative for oxidase, utilization of salicin, L-fucose, caprate, citrate and phenylacetate, and activities of alkaline phosphatase, trypsin, $\alpha$-chymotrypsin, $\beta$-glucuronidase, $N$-acetyl- $\beta$-glucosaminidase and $\alpha$-fucosidase. + , Positive; -, negative; w, weakly positive; ND, not determined.

\begin{tabular}{|c|c|c|c|c|c|}
\hline Characteristic & 1 & 2 & 3 & 4 & 5 \\
\hline Cell morphology & Short rods/rods & Rods/cocci & Long rods & Rods/cocci & Short rods \\
\hline Motility & - & $\mathrm{W}$ & - & + & - \\
\hline Colony colour ${ }^{\star}$ & Greyish yellow & White-grey & Yellow & White & Bright yellow \\
\hline Growth at $7 \% \mathrm{NaCl}$ & - & - & + & - & - \\
\hline Nitrate reduction & - & + & - & + & + \\
\hline \multicolumn{6}{|l|}{ Hydrolysis of: } \\
\hline Casein & + & + & - & + & + \\
\hline Starch & - & + & + & + & + \\
\hline Urea & - & - & + & - & $\mathrm{ND}$ \\
\hline \multicolumn{6}{|l|}{ Utilization of: $\dagger$} \\
\hline L-Arabinose & - & + & + & - & - \\
\hline D-Mannose & + & + & + & + & - \\
\hline Melibiose & + & + & - & + & + \\
\hline L-Rhamnose & + & - & - & - & - \\
\hline D-Ribose & $\mathrm{w}$ & - & + & - & - \\
\hline D-Mannitol & + & + & - & + & - \\
\hline D-Sorbitol & + & + & - & + & - \\
\hline Adipate & $\mathrm{W}$ & $\mathrm{w}$ & - & $\mathrm{w}$ & - \\
\hline \multicolumn{6}{|l|}{ API ZYM† } \\
\hline Esterase (C4) & - & + & + & + & + \\
\hline Lipase (C14) & - & - & - & + & - \\
\hline Valine arylamidase & - & - & - & + & - \\
\hline Cystine arylamidase & + & - & - & - & + \\
\hline Naphthol-AS-BI-phosphohydrolase & - & + & + & + & $\mathrm{w}$ \\
\hline$\beta$-Glucosidase & - & - & - & $\mathrm{w}$ & - \\
\hline$\alpha$-Mannosidase & - & - & - & $\mathrm{w}$ & - \\
\hline Whole-cell sugars $\ddagger$ & $\begin{array}{c}\text { Glc, Man, Ara, } \\
\text { Xyl }\end{array}$ & ND & Fuc, Gal & $\begin{array}{l}\text { Glc, Rib, Rha, } \\
\text { Xyl, Gal }\end{array}$ & $\begin{array}{c}\text { Glc, Rha, Rib, } \\
\text { Xyl, Ara }\end{array}$ \\
\hline Polar lipids $\$$ & $\begin{array}{l}\text { DPG, PG, PE, } \\
\text { PI, PL, L }\end{array}$ & $\begin{array}{c}\text { DPG, PE, PI, } \\
\text { APGL }\end{array}$ & $\begin{array}{c}\text { DPG, PE, } \\
\text { PI, PGL }\end{array}$ & $\begin{array}{l}\text { DPG, PE, } \\
\text { PI, PL }\end{array}$ & $\begin{array}{c}\text { DPG, PE, PG, } \\
\text { PI, PL }\end{array}$ \\
\hline DNA G + C content $(\mathrm{mol} \%)$ & 71.6 & 73 & 71 & 71.7 & 72.6 \\
\hline
\end{tabular}

${ }^{*}$ Differences may be observed with different cultivation conditions.

$\dagger$ Data for T. tumescens and T. terrae were taken from Weon et al. (2007); data for T. lapilli were taken from this study.

¥Ara, Arabinose; Fuc, fucose; Gal, galactose; Glc, glucose; Man, mannose; Xyl, xylose; Rha, rhamnose; Rib, ribose.

§APGL, Unknown amino-containing phosphoglycolipid; DPG, diphosphatidylglycerol; PE, phosphatidylethanolamine; PI, phosphatidylinositol; PG, phosphatidylglycerol; PGL, unknown phosphoglycolipid; PL, unidentified phospholipid; L, unknown lipid. 
due to differences in cultivation and extraction conditions (Weon et al., 2007; Lee et al., 2008). The DNA G+C content of strain $\mathrm{ON} 10^{\mathrm{T}}$ was $71.6 \mathrm{~mol} \%$.

Strain $\mathrm{ON} 10^{\mathrm{T}}$ showed the closest phylogenetic affiliation to members of the genus Terrabacter. Moreover, there were no distinct chemotaxonomic properties that differentiated strain $\mathrm{ON} 10^{\mathrm{T}}$ from members of the genus Terrabacter (Montero-Barrientos et al., 2005; Weon et al., 2007; Lee et al., 2008). Accordingly, it is reasonable to place strain $\mathrm{ON} 10^{\mathrm{T}}$ within the genus Terrabacter. Strain $\mathrm{ON} 10^{\mathrm{T}}$ was distinguishable from recognized Terrabacter species by differences in several phenotypic characteristics, as shown in Table 1. Therefore, the phylogenetic and genetic distinctiveness and the differential phenotypic properties suggest that strain $\mathrm{ON} 10^{\mathrm{T}}$ represents a novel species of the genus Terrabacter, for which the name Terrabacter terrigena sp. nov. is proposed.

\section{Description of Terrabacter terrigena sp. nov.}

Terrabacter terrigena (ter.ri'ge.na. L. masc. or fem. n. terrigena child of the earth, earth-born, referring to the isolation of the type strain from soil).

Cells are aerobic, Gram-positive-staining, non-spore-forming, non-motile rods or short rods, $0.3-0.6 \times 1.0-5.0 \mu \mathrm{m}$. Colonies on TSA are circular, convex, sticky, glistening and greyish yellow, $1.5-2.0 \mathrm{~mm}$ in diameter after incubation for 7 days at $30{ }^{\circ} \mathrm{C}$. Growth occurs at 10 and $37{ }^{\circ} \mathrm{C}$, but not at 4 or $40{ }^{\circ} \mathrm{C}$, at $\mathrm{pH} 5.0$ and 8.5 but not at $\mathrm{pH} 4.5$ or 9.0 (optimum, $\mathrm{pH} 6.5-7.0)$ and in the presence of $0-3 \%(\mathrm{w} / \mathrm{v})$ $\mathrm{NaCl}$ (optimum, $0.5 \% \mathrm{NaCl}$ ). Arginine dihydrolase, lysine decarboxylase, ornithine decarboxylase and tryptophan deaminase are absent. $\mathrm{H}_{2} \mathrm{~S}$ and indole are not produced. Hypoxanthine and Tweens 20, 40 and 60 are hydrolysed, but xanthine, tyrosine and Tween 80 are not. D-Xylose, galactose, fructose, arbutin, aesculin, cellobiose, lactose, trehalose, melezitose, raffinose, starch, turanose, D-lyxose and D-arabitol are utilized as sole carbon and energy sources, but glycerol, erythritol, D-arabinose, L-xylose, adonitol, methyl $\beta$-D-xyloside, sorbose, dulcitol, methyl $\alpha$-D-mannoside, methyl $\alpha$-D-glucoside, amygdalin, inulin, xylitol, gentiobiose, D-tagatose, D-fucose, L-arabitol and 2and 5-ketogluconate are not. Susceptible to cephalothin, chloramphenicol, lincomycin, neomycin, oleandomycin, penicillin $G$, streptomycin and tetracycline, but not to ampicillin, carbenicillin, gentamicin, kanamycin, novobiocin or polymyxin $\mathrm{B}$. The cell-wall peptidoglycan contains LL-2,6-diaminopimelic acid as the diagnostic diamino acid. Cell-wall sugars are glucose, mannose, arabinose and xylose. Predominant menaquinone is $\mathrm{MK}-8\left(\mathrm{H}_{4}\right)$. Major polar lipids are diphosphatidylglycerol, phosphatidylglycerol, phosphatidylethanolamine, phosphatidylinositol, an unidentified phospholipid and an unidentified lipid. Major fatty acids ( $>10 \%$ of total fatty acids) are iso- $\mathrm{C}_{15: 0}$ and iso- $\mathrm{C}_{14: 0}$. Other phenotypic characteristics are given in Table 1 . The DNA $\mathrm{G}+\mathrm{C}$ content of the type strain is $71.6 \mathrm{~mol} \%$ (HPLC).
The type strain, $\mathrm{ON} 10^{\mathrm{T}}\left(=\mathrm{KCTC} 19602^{\mathrm{T}}=\mathrm{CCUG} 57508^{\mathrm{T}}\right)$, was isolated from soil around a wastewater treatment plant in Korea.

\section{Acknowledgements}

This work was supported by the research and development programme from the Ministry for Health, Welfare and Family Affairs of the Republic of Korea.

\section{References}

Collins, M. D., Dorsch, M. \& Stackebrandt, E. (1989). Transfer of Pimelobacter tumescens to Terrabacter gen. nov. as Terrabacter tumescens comb. nov. and of Pimelobacter jensenii to Nocardioides as Nocardioides jensenii comb. nov. Int J Syst Bacteriol 39, 1-6.

Cowan, S. T. \& Steel, K. J. (1965). Manual for the Identification of Medical Bacteria. London: Cambridge University Press.

Ezaki, T., Hashimoto, Y. \& Yabuuchi, E. (1989). Fluorometric deoxyribonucleic acid-deoxyribonucleic acid hybridization in microdilution wells as an alternative to membrane filter hybridization in which radioisotopes are used to determine genetic relatedness among bacterial strains. Int J Syst Bacteriol 39, 224-229.

Felsenstein, J. (1981). Evolutionary trees from DNA sequences: a maximum likelihood approach. J Mol Evol 17, 368-376.

Felsenstein, J. (1993). PHYLIP (phylogeny inference package), version 3.5. Distributed by the author. Department of Genome Sciences, University of Washington, Seattle, USA.

Jukes, T. H. \& Cantor, C. R. (1969). Evolution of protein molecules. In Mammalian Protein Metabolism, vol. 3, pp. 21-132. Edited by H. N. Munro. New York: Academic Press.

Kluge, A. G. \& Farris, J. S. (1969). Quantitative phyletics and the evolution of anurans. Syst Zool 18, 1-32.

Komagata, K. \& Suzuki, K. (1987). Lipid and cell-wall analysis in bacterial systematics. Methods Microbiol 19, 161-207.

Lányí, B. (1987). Classical and rapid identification methods for medically important bacteria. Methods Microbiol 19, 1-67.

Lee, J.-E., Seo, J. P., Lee, D. W., Ko, Y.-H. \& Lee, S. D. (2008). Terrabacter lapilli sp. nov., an actinomycete isolated from stone. Int $J$ Syst Evol Microbiol 58, 1084-1088.

Minnikin, D. E., O'Donnell, A. G., Goodfellow, M., Alderson, G., Athalye, M., Schaal, A. \& Parlett, J. H. (1984). An integrated procedure for the extraction of bacterial isoprenoid quinones and polar lipids. J Microbiol Methods 2, 233-241.

Montero-Barrientos, M., Rivas, R., Velázquez, E., Monte, E. \& Roig, M. G. (2005). Terrabacter terrae sp. nov., a novel actinomycete isolated from soil in Spain. Int J Syst Evol Microbiol 55, 2491-2495.

Saitou, N. \& Nei, M. (1987). The neighbor-joining method: a new method for reconstructing phylogenetic trees. Mol Biol Evol 4, 406425.

Sasser, M. (1990). Identification of bacteria by gas chromatography of cellular fatty acids, MIDI Technical Note 101. Newark, DE: MIDI Inc.

Stackebrandt, E., Rainey, F. A. \& Ward-Rainey, N. L. (1997). Proposal for a new hierarchic classification system, Actinobacteria classis nov. Int J Syst Bacteriol 47, 479-491.

Tamaoka, J. \& Komagata, K. (1984). Determination of DNA base composition by reversed-phase high-performance liquid chromatography. FEMS Microbiol Lett 25, 125-128.

Thompson, J. D., Higgins, D. G. \& Gibson, T. J. (1994). CLUSTAL W: improving the sensitivity of progressive multiple sequence alignment 
through sequence weighting, position-specific gap penalties and weight matrix choice. Nucleic Acids Res 22, 4673-4680.

Wayne, L. G., Brenner, D. J., Colwell, R. R., Grimont, P. A. D., Kandler, O., Krichevsky, M. I., Moore, L. H., Moore, W. E. C., Murray, R. G. E. \& other authors (1987). International Committee on Systematic Bacteriology. Report of the ad hoc committee on reconciliation of approaches to bacterial systematics. Int J Syst Bacteriol 37, 463-464.

Weon, H.-Y., Schumann, P., Kroppenstedt, R. M., Kim, B.-Y., Song, J., Kwon, S.-W., Go, S.-J. \& Stackebrandt, E. (2007). Terrabacter aerolatus sp. nov., isolated from an air sample. Int J Syst Evol Microbiol 57, 2106-2109.
Yoon, J.-H., Kim, H., Kim, S.-B., Kim, H.-J., Kim, W. Y., Lee, S. T., Goodfellow, M. \& Park, Y.-H. (1996). Identification of Saccharomonospora strains by the use of genomic DNA fragments and rRNA gene probes. Int J Syst Bacteriol 46, 502-505.

Yoon, J.-H., Lee, S. T. \& Park, Y.-H. (1998). Inter- and intraspecific phylogenetic analysis of the genus Nocardioides and related taxa based on 16S rRNA gene sequences. Int J Syst Bacteriol 48, 187-194.

Yoon, J.-H., Kang, K. H. \& Park, Y.-H. (2003). Psychrobacter jeotgali sp. nov., isolated from jeotgal, a traditional Korean fermented seafood. Int J Syst Evol Microbiol 53, 449-454. 